\title{
The competitiveness of the national economy: energy-related aspects
}

\author{
Eleonora Matuygina ${ }^{1,2^{*}}$, Tatiana Rumyantseva ${ }^{1}$, and Anastasiya Klabukova ${ }^{1}$ \\ ${ }^{1}$ National Research Tomsk State University (NR TSU), 36 Lenin Ave., Tomsk, 634050, Russia \\ ${ }^{2}$ Tomsk State University of Control Systems and Radioelectronics (TUSUR), 40 pr. Lenin, Tomsk, \\ 634050, Russia
}

\begin{abstract}
The aim of the paper is to assess the competitiveness of national production in terms of its resources and energy supply. The authors present the dynamics of energy intensity of some countries and regions of the world and consider the relationship between the level of energy intensity and the competitiveness of national economies. Based on this relationship, countries are grouped depending on the type of the performance indicators of economies. Alternative energy is presented as a tool for improving efficiency of existing industries and for ensuring countries' position in the world market. The increase in the share of renewable energy in total consumption served as a basis for studying experience of various countries in regulating the development of alternative energy followed by a grouping of methods. The paper analyses both methods associated with the positioning of alternative energy and its incorporation into the existing structure and methods aimed at stimulating the development of alternative energy.
\end{abstract}

\section{Introduction}

The expanded reproduction of living conditions together with population growth requires the intensive involvement of various types of resources in the economic turnover. According to the UN report "Population and Vital Statistic Report", the world population reached 7.3 billion people in 2014, and the increase was 5.5\% in 2018 ( 7.7 billion people) [1]. Over the same period, global GDP grew by 7.6\% (78 944.49 and 84929.51 trillion dollars, respectively) with an increase in energy consumption by 14.3\% (12231 and 13978 Mtoe, respectively) [2]. Because of the predominant orientation of national economies on the use of traditional energy sources in the conditions of resource constraints, such dynamics encourages the search for new energy sources and optimization of the process of energy production and consumption. An additional justification is the negative impact of traditional energy on the environment (for example, in 2018, CO2 emissions from burning fossil fuels reached $33.1 \mathrm{Gt} \mathrm{CO} 2$, i.e. increased by $1.7 \%$ in comparison with 2017 , and according to IEA (International Energy Agency), the energy sector accounted for almost two-thirds of emissions [3]).

\footnotetext{
* Corresponding author: emk512542@mail.ru
} 
Russian researchers (Trifilov D.I., Sergeev N.N. and others [4,5]) as well as foreign researchers (Kraft J., Kraft A; L.Liu, T.Chen and Y.Yin and others [6, 7]) cover the issues of energy efficiency. Moreover, Mardani A., Zavadskas E.K., Streimikiene D., Juson A. and Khoshnoudi M.A.; Zhang X.P., Cheng X.M.,Yuan J.H. and Gao X.J. [8, 9] focus on the symbiosis of economic (energy) and environmental components of the development of society.

\section{Data and results}

Table 1 presents the energy intensity data of some countries and regions of the world.

Table 1. Energy intensity of GDP (MJ/\$) [10].

\begin{tabular}{|l|l|l|l|l|l|l|l|}
\hline \multirow{2}{*}{ Region / country } & \multicolumn{7}{|c|}{ Year } \\
\cline { 2 - 8 } & 2005 & 2007 & 2009 & 2010 & 2015 & $\begin{array}{l}2025 \\
\text { (forecast) }\end{array}$ & $\begin{array}{l}2035 \\
\text { (forecast) }\end{array}$ \\
\hline Russia & 17.06 & 16.64 & 12.97 & 11.32 & 10.08 & 9.01 & 7.89 \\
\hline Canada & 14.63 & 14.27 & 13.47 & 11.95 & 11.03 & 10.18 & 9.43 \\
\hline South Korea & 13.43 & 13.27 & 10.31 & 8.55 & 7.76 & 7.14 & 9.28 \\
\hline USA & 10.06 & 9.92 & 8.49 & 7.58 & 6.97 & 5.97 & 5.37 \\
\hline $\begin{array}{l}\text { Australia and New } \\
\text { Zealand }\end{array}$ & 9.61 & 9.59 & 8.80 & 7.85 & 6.97 & 6.20 & 5.50 \\
\hline China & 7.47 & 8.14 & 6.58 & 5.48 & 4.65 & 3.99 & 3.46 \\
\hline European Union & 7.73 & 7.68 & 6.75 & 6.00 & 5.26 & 4.70 & 4.20 \\
\hline Japan & 7.12 & 7.09 & 6.41 & 6.01 & 5.75 & 5.53 & 5.32 \\
\hline Mexico & 7.03 & 6.85 & 6.78 & 6.16 & 5.58 & 4.97 & 4.44 \\
\hline Brazil & 6.66 & 6.64 & 6.51 & 5.59 & 5.10 & 4.68 & 6.09 \\
\hline India & 4.42 & 4.36 & 3.33 & 2.94 & 2.57 & 2.24 & 1.92 \\
\hline
\end{tabular}

China has one of the lowest energy intensity indicators $(4.65 \mathrm{MJ} / \$)$ and is one of the countries with the highest energy consumption, which is because of an unbalance between GDP growth rates and energy consumption (according to 2015 data, GDP growth of $6.9 \%$ was accompanied by an increase in energy consumption of only $1 \%$ ). In the USA, the GDP growth of $2.9 \%$ was accompanied by a decrease of $1 \%$ in energy consumption $[11,12]$. Let us analyze some countries and consider types of the performance indicators that have a direct impact on energy intensity (Table 2).

Table 2. Grouping of countries (according to data of $2007-2015[12,13]$ ).

\begin{tabular}{|l|l|l|}
\hline \multicolumn{2}{|c|}{ Country } \\
\hline \multicolumn{2}{|c|}{$\begin{array}{c}\text { Unidirectional causality from GDP growth to } \\
\text { energy consumption }\end{array}$} & $\begin{array}{l}\text { Bi-directional causality from } \\
\text { GDP growth to energy } \\
\text { consumption }\end{array}$ \\
\hline $\begin{array}{l}\text { GDP exceeds energy } \\
\text { consumption }\end{array}$ & $\begin{array}{l}\text { GDP lags behind energy } \\
\text { consumption }\end{array}$ & $\begin{array}{l}\text { GDP } \uparrow \text { energy } \\
\text { consumption } \downarrow * *\end{array}$ \\
\hline $\begin{array}{l}\text { Russia } \\
\left(125.10 / 105.51^{\mathrm{a}}\right)\end{array}$ & Iran $(115.28 / 123.04)$ & Japan $(116.04 / 84.40)$ \\
\hline $\begin{array}{l}\text { Canada } \\
(127.41 / 101.44)\end{array}$ & $\begin{array}{l}\text { United Arab Emirates } \\
(144.94 / 154.00)\end{array}$ & USA (126.07/93.84) \\
\hline \begin{tabular}{l} 
Brazil $(135.37 / 125.42)$ \\
\hline
\end{tabular} & Algeria (143.66/145.95) & Spain $(109.67 / 82.64)$ \\
\hline
\end{tabular}

arowth rate of GDP (\%)/ growth rate of energy consumption (\%) 
** the reverse trend is not observed in any country in the world

We understand that the competitiveness of the national economy is based on the dynamics of its development and the welfare of the population [14] and on the internal conditions for maintaining effectiveness of national exports [15] (and production in general). Therefore, we can note that energy intensity management is an important tool for creating competitive advantages, which is reinforced by actions to increase supply of energy resources.

Figures 1-2 show a comparison between the level of energy consumption (energy intensity of GDP) and the competitiveness rating for groups of countries.

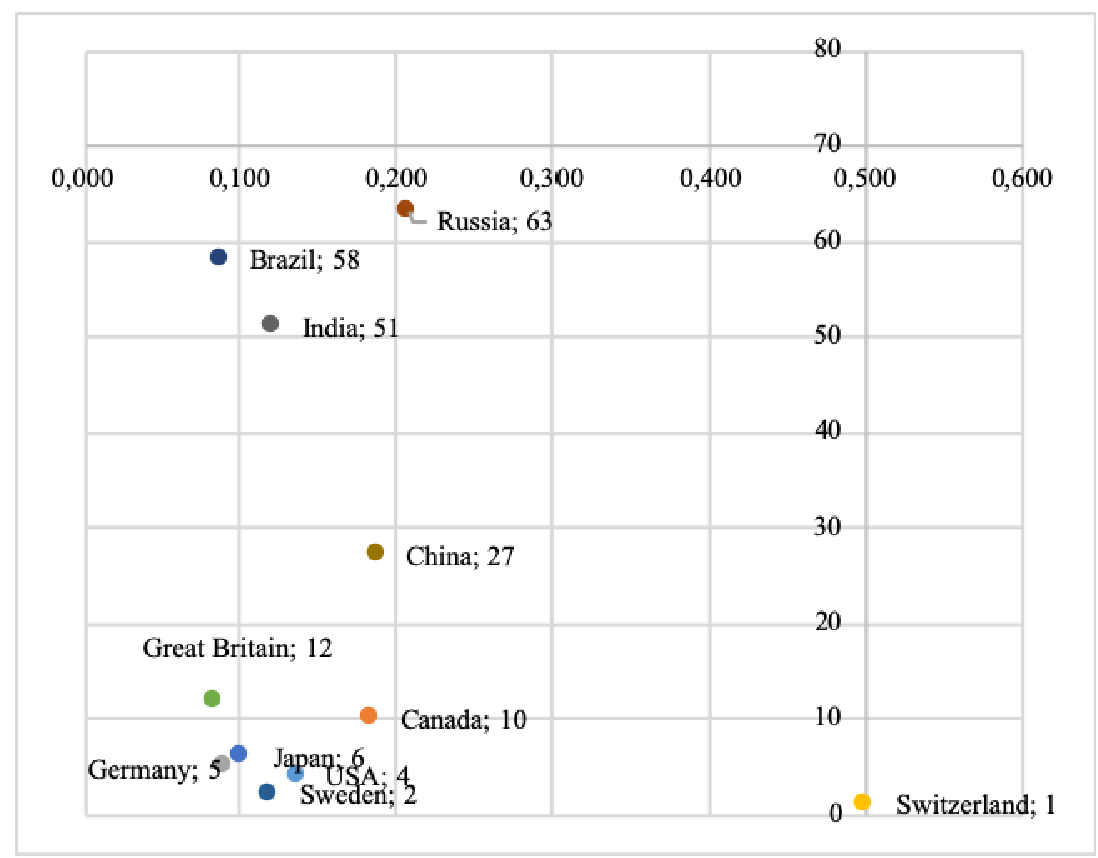

Fig.1. Dynamics of energy intensity and competitiveness (2010). 


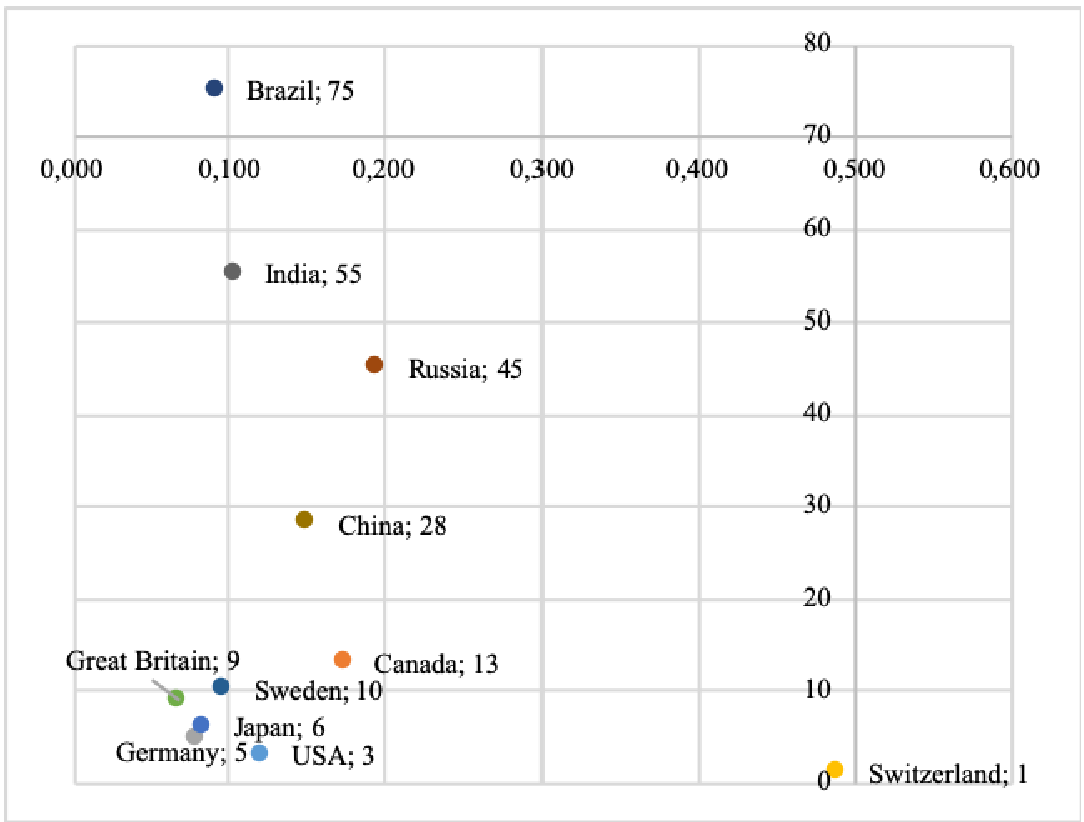

Fig.2. Dynamics of energy intensity and competitiveness (2015).

In addition, we should note that in certain countries, an increase in the competitiveness ranking could be accompanied by a decrease in energy intensity. Thus, the US shift in the ranking from the $4^{\text {th }}$ to $3^{\text {rd }}$ place was accompanied by a decrease in the energy intensity of GDP from 0.136 to $0.121 \mathrm{~kg}$ of oil equivalent per US\$. Russia's shift from the $63^{\text {rd }}$ to $45^{\text {th }}$ was accompanied by a decrease in energy intensity from 0.207 to $0.109 \mathrm{~kg}$ of oil equivalent per US\$. However, the opposite changes are also possible, which is proved by the example of Canada, Sweden, India, China, etc. We should also note that China is a market leader in the production of solar modules. In 2017, China and Taiwan accounted for about $70 \%$ of the global volume of solar panels [16].

Traditional energy resource constraints are both a threat to the sustainable development of the international community and an incentive to acquire new competitive advantages. We mean alternative energy, which on the one hand, is a tool for maintaining or increasing the competitiveness of existing industries, and on the other hand, is an independent direction of cross-country competition (in terms of technology development).

According to the Global Energy Statistical Yearbook (2018), the share of renewable sources in total consumption grew by $1 \%$ to an average level of $26 \%$ in the world (USA $17.5 \%$, Germany $-36.0 \%$, Switzerland - less than $10 \%$, Japan $-17.5 \%$, Sweden $-55.3 \%$, Russia - $17.2 \%$, China $-26.3 \%$, etc.) [17].

Table 3 presents the methods for the alternative energy development used in different countries of the world [18].

Table 3. Incentive methods

\begin{tabular}{|c|c|c|}
\hline Purpose & Method & Content \\
\hline $\begin{array}{c}\text { Positioning of } \\
\text { alternative energy, } \\
\text { integration into the } \\
\text { current structure of } \\
\text { consumption }\end{array}$ & $\begin{array}{c}\text { The Public Utility } \\
\text { Regulatory Policies Act } \\
\text { (USA, 1978) }\end{array}$ & $\begin{array}{c}\text { Reduced consumption of fossil } \\
\text { resources by stimulating the use of } \\
\text { alternative energy. }\end{array}$ \\
\cline { 2 - 3 } & $\begin{array}{c}\text { The Renewable Energy } \\
\text { Sources Act (Germany, } \\
1991 \text { ) }\end{array}$ & $\begin{array}{c}\text { The obligation of network operators to } \\
\text { purchase energy from enterprises using } \\
\text { renewable energy sources. }\end{array}$ \\
\hline
\end{tabular}




\begin{tabular}{|c|c|c|}
\hline & $\begin{array}{l}\text { The 10th five-year Plan of } \\
\text { Economic and Social } \\
\text { Development of the } \\
\text { People's Republic of } \\
\text { China }\end{array}$ & $\begin{array}{l}\text { Determination of the need to use } \\
\text { renewable energy sources and the } \\
\text { goals and trends of alternative energy } \\
\text { development. }\end{array}$ \\
\hline \multirow[t]{2}{*}{$\begin{array}{l}\text { Stimulating the } \\
\text { production and the } \\
\text { development of } \\
\text { alternative energy }\end{array}$} & Green Tariffs (USA) & $\begin{array}{l}\text { Increasing tariffs for alternative energy } \\
\text { by } 10-20 \% \text {; contracts between the state } \\
\text { and private companies for the purchase } \\
\text { of alternative energy. }\end{array}$ \\
\hline & $\begin{array}{c}\text { Compensation Plan } \\
\text { (USA) }\end{array}$ & $\begin{array}{l}\text { The purchase price is set at the level of } \\
\text { real costs; all additional costs for } \\
\text { companies are compensated. }\end{array}$ \\
\hline \multirow[t]{2}{*}{$\begin{array}{l}\text { Stimulating the } \\
\text { production and the } \\
\text { development of } \\
\text { alternative energy }\end{array}$} & $\begin{array}{l}\text { Quota model (European } \\
\text { countries - Great Britain, } \\
\text { Sweden, Austria, } \\
\text { Belgium, etc.) }\end{array}$ & $\begin{array}{l}\text { The state allocated quotas ("green } \\
\text { certificates") for the production of } \\
\text { alternative energy. If the level of } \\
\text { produced energy exceeded the quota, } \\
\text { the company was eligible to sell the } \\
\text { surplus to other companies at market } \\
\text { prices. If the level of produced energy } \\
\text { was less than the quota, the company } \\
\text { bought the missing volume from other } \\
\text { companies (with excess) or paid a fine. }\end{array}$ \\
\hline & $\begin{array}{l}\text { Golden Sun Program } 2009 \\
\text { (People's Republic of } \\
\text { China) }\end{array}$ & $\begin{array}{l}\text { Subsidies up to } 70 \% \text { of the production } \\
\text { cost to manufacturers of solar panels } \\
\text { were established. }\end{array}$ \\
\hline
\end{tabular}

\section{Conclusion}

Thus, we can consider the level of energy intensity not only as one of the criteria for evaluating competitiveness of the national economy, but also as a tool for its formation / strengthening. Despite the existence of a significant number of factors determining the competitiveness of the national economy, we can perceive energy management as the basic factor that ensures national production as a whole.

\section{References}

1. United Nations, Population and Vital Statistic Report, Statistical Papers Series A, LXXI (ST/ESA/SER.A/265), (2019)

2. Knoema Eterprises, [https://knoema.ru/atlas/\%D0\%92\%D0\%B5\%D1\%81\%D1\%8C$\% \mathrm{D} 0 \% \mathrm{BC} \% \mathrm{D} 0 \% \mathrm{~B} 8 \% \mathrm{D} 1 \% 80 / \% \mathrm{D} 0 \% 92 \% \mathrm{D} 0 \% 92 \% \mathrm{D} 0 \% 9 \mathrm{~F}]$.

3. Global Energy and CO2 Status Report, [https://www.iea.org/geco/emissions/].

4. D.I. Trifilov, Energy efficiency as one of the elements of competitiveness of the Russian economy, Modern competition, 4, 96, (2012).

5. N.N. Sergeev, Theoretical aspects of energy saving and energy efficiency of industrial enterprises, Vestnik of Astrakhan State Technical University. Series: Economics, 1, 2936, (2013).

6. J. Kraft, A. Kraft, Journal of Energy and Development, 3.401-403 (1978)

7. L. Liu, T. Chen, Y. Yin, Energy Procedia. 88. 224-229 (2016)

8. X.P. Zhang, X.M. Cheng, J.H. Yuan, X.J. Gao, EnergyPolicy, 39(2). 644-650 (2011) 
9. A. Mardani, E.K. Zavadskas, D. Streimikiene, A. Juson, M. Khoshnoudi, Renewable \& Sustainable Energy Reviews, 70. 1298-1322 (2017)

10. Samarina V.P. Innovative economy: prospects for development and improvement, 5(15), 133-138, (2016)

11. The World Bank, GDP, [https://data.worldbank.org/indicator/NY.GDP.MKTP.CD]

12. Total energy consumption [https://yearbook.enerdata.ru/total-energy/worldconsumption-statistics.html]

13. World GDP Ranking, [http://svspb.net/danmark/vvp-stran.php]

14. I.S. Bondarenko, Economy of Industry, 3 (38) (2007).

15. M.V. Loskutova, Tomsk State University Journal, 2 (2009).

16. The largest manufacturers of solar modules in 2017, [http://renen.ru/the-largestmanufacturers-of-solar-modules-in-2017]

17. Share of renewables in electricity [https://yearbook.enerdata.net/renewables/renewablein-electricity-production-share.html]

18. O.I. Malikova, M.A. Zlatnikova Public administration. E-journal: 17, 5- 30 (2019). 